\title{
Research Opportunities for Supplier Selection: An Analysis from Literature Reviews
}

\author{
Jose Alejandro CANO ${ }^{1}$ and Carlos Javier AYALA ${ }^{2}$ \\ ${ }^{1}$ Universidad de Medellín, Medellín, Colombia \\ ${ }^{2}$ Fundación Universitaria CEIPA, Medellín, Colombia
}

Correspandance should be adressed to : Jose Alejandro CANO; jacano@udem.edu.co

Received date: 19 April 2019; Accepted date:18 June 2019; Published date: 4 September 2019

Academic Editor: Ricardo De la Hoz Lara

Copyright (C) 2019. Jose Alejandro CANO and Carlos Javier AYALA. Distributed under Creative Commons CC-BY 4.0

\begin{abstract}
This article aims to identify different literature reviews of supplier selection to analyze the topics addressed in these documents, and suggest research opportunities for future literature reviews in issues that have not been addressed in the literature or require a deeper approach. This study states that the majority of existing literature reviews focus on the analysis of supplier selection methods and criteria, and uncertainty management, environmental management, and sustainability have been addressed in recent years. As a conclusion, it is suggested to focus future literature reviews on topics such as risk management, statistical methods, methods applied to industry sectors, implementation of supplier selection to small and medium enterprises, comparative analysis of solution methods performance, and the adaptation of solution methods from areas different to supplier selection. Likewise, it is recommended to continue updating literature reviews related to green and sustainable supplier selection, and uncertainty management in supplier selection, especially for the last 3-5 years.
\end{abstract}

Keywords: Supplier selection, supplier evaluation, literature review, supply chain

\section{Introduction}

Supply chain management (SCM) is defined as the planning, execution, and control of operations and flows of products, finances, and information within and between companies, from primary sources to final consumers (Cano, Panizo, García, \& Rodríguez, 2015). Therefore, SCM must integrate business units to satisfy the

Cite this Article as: Jose Alejandro CANO and Carlos Javier AYALA (2019)," Research Opportunities for Supplier Selection: An Analysis from Literature Reviews ", IBIMA Business Review, Vol. 2019 (2019), Article ID 828922, DOI: $10.5171 / 2019.828922$ 
demand of final consumers, improving the competitiveness and all material flows from raw materials to finished products (AminTahmasbi \& Alfi, 2018).

For a proper integration of the links in a supply chain, it is essential to perform efficient sourcing and purchasing processes (Aissaoui, Haouari, \& Hassini, 2007), which are responsible for acquiring goods, components and services from suppliers, guaranteeing the viability of operations in a company through inflows and resource availability (Drake, Myung Lee, \& Hussain, 2013). Therefore, the procurement and purchasing process represents a highly important role in most industries, to the point of representing between $70-80 \%$ of the total production cost, thus, a small reduction in purchasing costs can lead to a substantial increase in efficiency and profitability in companies (Ghodsypour \& O’Brien, 2001; Murray, 2009).

Additionally, companies have increasingly been interested in reducing the number of suppliers to establish long-term relationships with reliable partners to improve the supply chain performance (Abdolshah, 2013; Kellner, Lienland, \& Utz, 2018). Consequently, supplier selection is one of the most important and fundamental decisions in procurement and purchasing processes, drawing significant attention in the literature and practice due to the degree of difficulty involved in this multi-criteria decision-making process (Boran, Genç, Kurt, \& Akay, 2009; Chai, Liu, \& Ngai, 2013).
As supplier selection provides useful information to managers in supply chains and purchasing processes, it is necessary to review current studies in the literature in order to identify trends, research opportunities, criteria selection, uncertainty management, and supplier selection methods to support strategic plans in companies (Alkahtani \& Kaid, 2018; Gómez, Cano \& Campo, 2016). This implies focusing on each supplier selection stage such as identifying the competitive strategy, formulating criteria and indicators, developing new selection methods, selecting candidate suppliers, final supplier selection, formulation of supplier development programs, performance evaluation, among others (Chen, 2011; Zimmer, Fröhling, \& Schultmann, 2016).

Accordingly, several literature reviews differ in their approach to supplier selection activities, the period analyzed, and the new studies and developments in these periods. For instance, Scopus provides 1,766 documents between 2000 and 2018 as a result of the search equation "supplier selection" in the field "article title", therefore, it is necessary to update existing literature reviews for supplier selection. Figure 1 shows the number of publications related to supplier selection and the growing trend of these publications in the last three years, where $30 \%$ of documents on supplier selection (525 publications) were published between 2016 and 2018, and $90 \%$ of documents were published between 2008 and 2018.

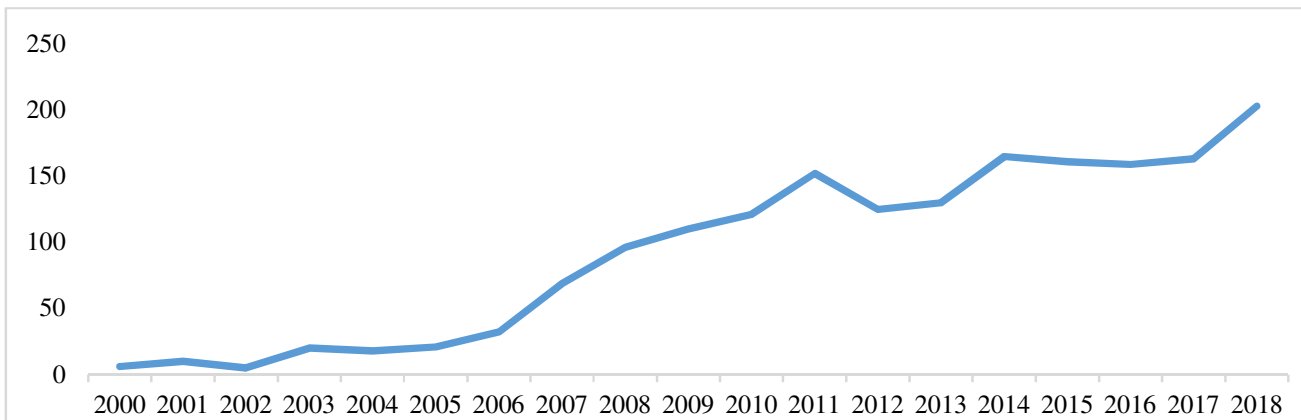

Fig.1: Number of documents published in Scopus related to supplier selection 
Therefore, this article aims to identify the different literature reviews related to supplier selection to analyze the issues addressed therein and highlight research opportunities to conduct literature reviews based on previous studies or based on topics that have not yet been fully addressed in the scientific and academic field.

\section{Literature reviews of supplier selection}

As shown in Table 1, a wide variety of literature reviews of supplier selection has emerged since 2000, focusing on topics such as solution methods, analysis of the most recurrent and important criteria, uncertainty management for the decisionmaking process, application of supplier selection to industrial sectors, and other relevant issues.

Table 1: Main topics addressed in literature reviews of supplier selection

\begin{tabular}{|c|c|c|c|c|c|c|}
\hline Authors & $\begin{array}{l}\text { Method } \\
\text { s }\end{array}$ & $\begin{array}{c}\text { Criter } \\
\text { ia }\end{array}$ & $\begin{array}{l}\text { Uncertai } \\
\text { nty }\end{array}$ & $\begin{array}{c}\text { Green } \\
\text { Suppliers, } \\
\text { Sustainability }\end{array}$ & $\begin{array}{l}\text { Industr } \\
\text { ial } \\
\text { Sectors }\end{array}$ & $\begin{array}{l}\text { Other } \\
\text { Topic } \\
\text { S }\end{array}$ \\
\hline $\begin{array}{l}\text { (De Boer, Labro, \& } \\
\text { Morlacchi, 2001) }\end{array}$ & $\mathrm{x}$ & & & & & \\
\hline (Aamer \& Sawhney, 2004) & $\mathrm{x}$ & & & & & \\
\hline (Aissaoui et al., 2007) & & & & & & $\mathrm{x}$ \\
\hline (Ho, Xu, \& Dey, 2010) & $\mathrm{x}$ & $\mathrm{x}$ & & & & \\
\hline $\begin{array}{l}\text { (Agarwal, Sahai, Mishra, } \\
\text { Bag, \& Singh, 2011) }\end{array}$ & $\mathrm{x}$ & & & & & \\
\hline $\begin{array}{l}\text { (Deshmukh \& Chaudhari, } \\
\text { 2011) }\end{array}$ & $\mathrm{x}$ & $\mathrm{x}$ & & & & \\
\hline $\begin{array}{ll}\text { (Setak, } \quad \text { Sharifi, } & \& \\
\text { Alimohammadian, 2012) } & \end{array}$ & $\mathrm{x}$ & $\mathrm{x}$ & & & & \\
\hline (Viana \& Alencar, 2012) & $\mathrm{x}$ & $x$ & & & & \\
\hline (Abdolshah, 2013) & $\mathrm{x}$ & $\mathrm{x}$ & & & & \\
\hline (Chai et al., 2013) & $\mathrm{x}$ & & $\mathrm{x}$ & & & \\
\hline $\begin{array}{l}\text { (Igarashi, De Boer, \& Fet, } \\
\text { 2013) }\end{array}$ & & & & $\mathrm{x}$ & & \\
\hline $\begin{array}{l}\text { (Junior, Osiro, \& Carpinetti, } \\
\text { 2013) }\end{array}$ & $\mathrm{x}$ & & $\mathrm{x}$ & & & \\
\hline $\begin{array}{l}\text { (Khodadadzadeh \& Sadjadi, } \\
\text { 2013) }\end{array}$ & $\mathrm{x}$ & & & & & \\
\hline $\begin{array}{l}\text { (Zhang, Abdul Hamid, \& } \\
\text { Thoo, 2014) }\end{array}$ & & & & $\mathrm{x}$ & & \\
\hline (Chakraborty, 2015) & & & & & $\mathrm{x}$ & \\
\hline (Ghadimi \& Heavey, 2015) & & & & & & $\mathrm{x}$ \\
\hline $\begin{array}{l}\text { (Govindan, } \quad \text { Rajendran, } \\
\text { Sarkis, \& Murugesan, 2015) }\end{array}$ & $\mathrm{x}$ & $\mathrm{x}$ & & $\mathrm{x}$ & & \\
\hline $\begin{array}{l}\text { (Villanueva-Ponce, Avelar- } \\
\text { Sosa, Alvarado-Iniesta, \& } \\
\text { Cruz-Sánchez, 2015) }\end{array}$ & $\mathrm{x}$ & $\mathrm{x}$ & & $\mathrm{x}$ & & \\
\hline (Yildiz \& Yayla, 2015) & $\mathrm{x}$ & $\mathrm{x}$ & & & $\mathrm{x}$ & \\
\hline (Karsak \& Dursun, 2016) & $\mathrm{x}$ & & $\mathrm{x}$ & & & \\
\hline $\begin{array}{l}\text { (My Dung, Luan, \& Quoc, } \\
\text { 2016) }\end{array}$ & $\mathrm{x}$ & & & $\mathrm{x}$ & & \\
\hline (Zimmer et al., 2016) & $\mathrm{x}$ & $\mathrm{x}$ & & $\mathrm{x}$ & & \\
\hline
\end{tabular}

Jose Alejandro CANO and Carlos Javier AYALA (2019), IBIMA Business Review, 


\begin{tabular}{|l|c|c|c|c|c|c|}
\hline $\begin{array}{l}\text { (Ghorabaee, } \\
\text { Zavadskas, } \\
\text { Antucheviciene, 2017) }\end{array}$ & $\mathrm{x}$ & & $\mathrm{x}$ & & & \\
\hline (Renganath, 2017) & $\mathrm{x}$ & & $\mathrm{x}$ & & & \\
\hline $\begin{array}{l}\text { (Simić, Kovačević, Svirčević, } \\
\text { \& Simić, 2017) }\end{array}$ & $\mathrm{x}$ & & $\mathrm{x}$ & & & \\
\hline (Alkahtani \& Kaid, 2018) & $\mathrm{x}$ & $\mathrm{x}$ & & & & \\
\hline $\begin{array}{l}\text { (Ristono, Pratikto, Santoso, } \\
\text { \& Tama, 2018) }\end{array}$ & $\mathrm{x}$ & & & & \\
\hline $\begin{array}{l}\text { Ocampo, Abad, Cabusas, } \\
\text { Padon, \& Sevilla, 2018) }\end{array}$ & $\mathrm{x}$ & & & & & \\
\hline
\end{tabular}

Table 1 shows that the majority of literature reviews (79\%) focus on the analysis of methods and techniques to solve the supplier selection problem, and in the analysis of criteria, variables and factors used for supplier evaluation (39\%). As for the uncertainty management, the documents of Chai et al. (2013), Junior et al. (2013), Karsak \& Dursun (2016), Ghorabaee et al. (2017), Renganath (2017) and Simić et al. (2017) analyze supplier selection methods for non-deterministic environments, highlighting the prevalence of methods based on fuzzy logic. Likewise, the studies of Igarashi et al. (2013), Govindan et al. (2015), Villanueva-Ponce et al. (2015) and My Dung et al. (2016) provide literature reviews of green supplier selection; whereas Zhang et al. (2014) and Zimmer et al. (2016) present literature reviews of sustainable supplier selection.

On the other hand, Chakraborty (2015) and Yildiz \& Yayla (2015) study the application areas of supplier selection methods, while Aissaoui et al. (2007) analyze the entire purchasing process both for materials and parts and for contracting activities and operations in companies under Internetbased procurement environments. Similarly, Table 1 identifies that since 2001 the study of methods and criteria for supplier selection has prevailed as the central topic in literature reviews, and, later on, the uncertainty management, environmental management, and sustainability began to be relevant in literature reviews from 2013.

Analyzing the number of literature reviews per year, Figure 2 shows that this type of documents is growing over time, highlighting the importance of continuing analyzing new trends and research opportunities in topics related to supplier selection. Likewise, it is highlighted that the largest number of these documents was published in 2013 (five literature reviews), focusing on topics such as supplier selection methods, supplier selection criteria, uncertainty management, and environmental management.

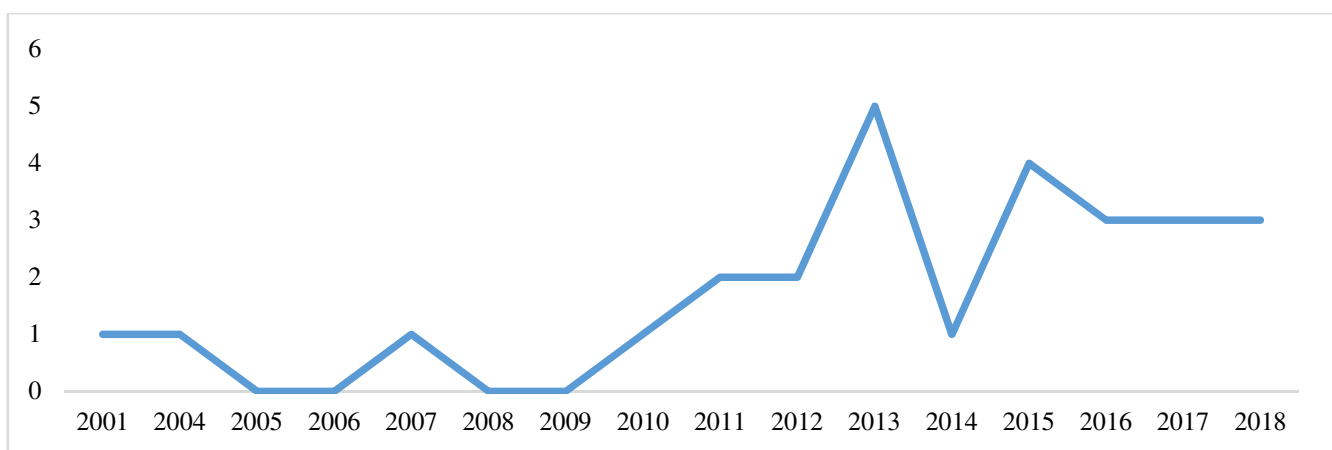

Fig. 2: Number of literature reviews of supplier selection per year 
An extensive list of journals publishing literature reviews of supplier selection was found, indicating that there is no more than one literature review between 2001 and 2018 in the same journal. The journals publishing literature reviews of supplier selection are Applied Mechanics And Materials, Arpn Journal of Engineering And Applied Sciences, Communications In Computer And Information Science, Computers And Operations Research, Decision Science Letters, Dyna Colombia, Economic Research Ekonomska Istrazivanja, European Journal of Operational Research, European Journal of Purchasing And Supply Management, Expert Systems With Applications, Gestao E Producao, International Journal of Business Performance And Supply Chain Modelling, International Journal of Computer Integrated Manufacturing, International Journal of Industrial Engineering Computations, International Journal of Integrated Supply Management, International Journal of Production Research, Journal Of Applied Logic, Journal of Cleaner Production, Journal of Industrial Engineering And Management, Journal of Purchasing And Supply Management, Journal of Quality And Reliability Engineering, Producao, South African Journal Of Industrial Engineering, World Applied Sciences Journal. This list shows that literature reviews are usually published in journals whose areas of study are mainly related to engineering, business, management and accounting, computer science, decision science, and mathematics, demonstrating the interdisciplinary nature and multiple approaches of the supplier selection process in the scientific and academic field.

On the other hand, the journals with the highest number of supplier selection articles between 2000 and 2018 are Expert Systems With Applications, International Journal of Production Economics, International Journal of Production Research, International Journal of Advanced Manufacturing Technology, Computers And
Industrial Engineering, Journal of Cleaner Production, Applied Mechanics And Materials, Mathematical Problems In Engineering, International Journal of Logistics Systems And Management, International Journal of Services And Operations Management, in which 19\% of the documents related to supplier selection are published.

Based on journals publishing literature reviews, it is found that in International Journal of Production Economics, International Journal of Advanced Manufacturing Technology, Computers And Industrial Engineering, Mathematical Problems In Engineering, International Journal of Logistics Systems And Management, International Journal of Services And Operations Management there are no literature reviews of supplier selection. This represents an opportunity for the publication of this type of documents because these journals have published between 18 and 50 documents that directly address supplier selection. Although the literature review of Chai et al. (2013) has been published in Expert Systems With Applications, this journal represents an opportunity for further literature reviews since it is the one with the highest number of publications of supplier selection (73 documents), including 27 published since the publication of Chai et al. (2013).

Regarding the areas of knowledge, supplier selection documents stand out in the same areas as the literature reviews, mainly in the area of engineering, followed by the areas of computer science, business, management and accounting, decision science, and mathematics.

Table 2 presents the main characteristics of the literature reviews of supplier selection, showing the period covered, the number of documents analyzed, databases consulted, and the publisher related to each literature review. 
Table 2: Characteristics of literature reviews of supplier selection

\begin{tabular}{|c|c|c|c|c|}
\hline Authors & Period & $\begin{array}{c}\# \\
\text { Doc. }\end{array}$ & Consulted Databases & Publisher \\
\hline (De Boer et al., 2001) & $\begin{array}{l}1969- \\
2000\end{array}$ & $\mathrm{~N} / \mathrm{A}$ & N/A & Pergamon \\
\hline $\begin{array}{l}\text { (Aamer \& Sawhney, } \\
\text { 2004) }\end{array}$ & $\begin{array}{l}1969- \\
2002\end{array}$ & 45 & N/A & IIE Proceedings \\
\hline (Aissaoui et al., 2007) & $\begin{array}{l}1966- \\
2005\end{array}$ & $\mathrm{~N} / \mathrm{A}$ & N/A & Elsevier \\
\hline (Ho et al., 2010) & $\begin{array}{l}2000- \\
2008\end{array}$ & 78 & $\begin{array}{l}\text { Emerald, Ingenta, Meta- Press, ProQuest, } \\
\text { ScienceDirect }\end{array}$ & Elsevier \\
\hline (Agarwal et al., 2011) & $\begin{array}{l}2000- \\
2011\end{array}$ & 68 & N/A & Growing Science \\
\hline $\begin{array}{l}\text { (Deshmukh \& } \\
\text { Chaudhari, 2011) }\end{array}$ & $\begin{array}{l}1992- \\
2007\end{array}$ & 49 & $\mathrm{~N} / \mathrm{A}$ & Springer \\
\hline (Setak et al., 2012) & $\begin{array}{l}2000- \\
2010\end{array}$ & 170 & N/A & $\begin{array}{l}\text { International Digital } \\
\text { Organization for } \\
\text { Scientific Information }\end{array}$ \\
\hline (Viana \& Alencar, 2012) & $\begin{array}{l}1998- \\
2011\end{array}$ & 56 & $\mathrm{~N} / \mathrm{A}$ & $\begin{array}{l}\text { Associacao Brasileira } \\
\text { de Engenharia de } \\
\text { Producao }\end{array}$ \\
\hline (Abdolshah, 2013) & $\mathrm{N} / \mathrm{A}$ & $\mathrm{N} / \mathrm{A}$ & $\mathrm{N} / \mathrm{A}$ & $\begin{array}{l}\text { Hindawi Publishing } \\
\text { Corporation }\end{array}$ \\
\hline (Chai et al., 2013) & $\begin{array}{l}2008- \\
2012\end{array}$ & 123 & $\begin{array}{l}\text { Science Direct, Emerald, Springer-Link } \\
\text { Journals, IEEE Xplore, Academic Search } \\
\text { Premier, World Scientific Net }\end{array}$ & Elsevier \\
\hline (Igarashi et al., 2013) & $\begin{array}{l}1991- \\
2011\end{array}$ & 60 & $\begin{array}{l}\text { Science Direct, Scopus, ProQuest ABI- } \\
\text { Inform }\end{array}$ & Elsevier \\
\hline (Junior et al., 2013) & $\begin{array}{l}2000- \\
2008\end{array}$ & 120 & $\begin{array}{l}\text { Science Direct, Web of Science, Scopus, } \\
\text { Emerald }\end{array}$ & $\begin{array}{l}\text { Universidade Federal } \\
\text { de Sao Carlos }\end{array}$ \\
\hline $\begin{array}{l}\text { (Khodadadzadeh \& } \\
\text { Sadjadi, 2013) }\end{array}$ & $\begin{array}{l}2000- \\
2012 \\
\end{array}$ & 123 & N/A & Growing Science \\
\hline (Zhang et al., 2014) & $\mathrm{N} / \mathrm{A}$ & $\mathrm{N} / \mathrm{A}$ & N/A & $\begin{array}{l}\text { Scitec Publications } \\
\text { Ltd. }\end{array}$ \\
\hline (Chakraborty, 2015) & $\begin{array}{l}2005- \\
2015\end{array}$ & 52 & $\mathrm{~N} / \mathrm{A}$ & $\begin{array}{l}\text { Research India } \\
\text { Publications }\end{array}$ \\
\hline $\begin{array}{l}\text { (Ghadimi \& Heavey, } \\
\text { 2015) }\end{array}$ & $\mathrm{N} / \mathrm{A}$ & 43 & \begin{tabular}{|l|} 
Sciencedirect, Scopus, GoogleScholar, \\
Springerlink, Tandfonline, Emeraldinsight, \\
Web of Knowledge \\
\end{tabular} & Eurosim Proceedings \\
\hline (Govindan et al., 2015) & $\begin{array}{l}1996- \\
2011\end{array}$ & 33 & \begin{tabular}{|l} 
Science Direct, Emerald Publishers, \\
Springer, IEEE, Taylor \& Francis, Google \\
Scholar.
\end{tabular} & Elsevier \\
\hline $\begin{array}{l}\text { (Villanueva-Ponce et al., } \\
\text { 2015) }\end{array}$ & $\begin{array}{l}2007- \\
2013\end{array}$ & 34 & Science Direct, IEEE, and ProQuest & $\begin{array}{l}\text { Universidad Nacional } \\
\text { de Colombia }\end{array}$ \\
\hline (Yildiz \& Yayla, 2015) & $\begin{array}{l}2001- \\
2014\end{array}$ & 91 & $\mathrm{~N} / \mathrm{A}$ & $\begin{array}{l}\text { South African Institute } \\
\text { of Industrial Engineers }\end{array}$ \\
\hline $\begin{array}{l}\text { (Karsak \& Dursun, } \\
\text { 2016) }\end{array}$ & $\begin{array}{l}2001- \\
2013\end{array}$ & 149 & \begin{tabular}{|l} 
EBSCO, Emerald, IEEE Xplore, ProQuest, \\
ScienceDirect, SpringerLink, Taylor \& \\
Francis, and Wiley Online Library \\
\end{tabular} & Taylor \& Francis \\
\hline (My Dung et al., 2016) & $\begin{array}{l}2002- \\
2014\end{array}$ & 36 & Elsevier, ProQuest, Emerald, and Springer & ARPN Journal \\
\hline (Zimmer et al., 2016) & $\begin{array}{l}1997- \\
2014\end{array}$ & 55 & $\begin{array}{l}\text { Scopus, CrossRef, EBSCOhost, } \\
\text { ScienceDirect, Emerald Insight, Springer } \\
\text { Link, Taylor \& Francis Online, Wiley Online } \\
\text { Library, Google Scholar }\end{array}$ & Taylor \& Francis \\
\hline (Ghorabaee et al., 2017) & $\begin{array}{l}2001- \\
2016\end{array}$ & 339 & $\begin{array}{l}\text { Web of Science, Scopus, EBSCO, ProQuest, } \\
\text { IEEE Xplore Digital Library, Scientific.Net, } \\
\text { ScienceDirect, Emerald, Springer, Taylor \& } \\
\text { Francis, CrossRef, DOAJ, ASME }\end{array}$ & Taylor \& Francis \\
\hline (Renganath, 2017) & $\begin{array}{l}2000- \\
2016\end{array}$ & 38 & ScienceDirect & IEEE Proceedings \\
\hline (Simić et al., 2017) & $\begin{array}{l}1966- \\
2016\end{array}$ & 54 & $\mathrm{~N} / \mathrm{A}$ & Elsevier \\
\hline
\end{tabular}

Jose Alejandro CANO and Carlos Javier AYALA (2019), IBIMA Business Review, DOI: $10.5171 / 2019.828922$ 


\begin{tabular}{|l|c|c|l|l|}
\hline (Alkahtani \& Kaid, 2018) & $\begin{array}{c}1995- \\
2018\end{array}$ & 80 & Web of science & $\begin{array}{l}\text { Inderscience } \\
\text { Enterprises Ltd }\end{array}$ \\
\hline (Ristono et al., 2018) & $\begin{array}{c}2008- \\
2018\end{array}$ & 34 & $\begin{array}{l}\text { Elsevier, Emerald, Springer-Link Journal, } \\
\text { Francis \& Taylor, Inderscience, Sage } \\
\text { publishing, World Scientific }\end{array}$ & Omniascience \\
\hline (Ocampo et al., 2018) & $\begin{array}{c}2006- \\
2016\end{array}$ & 244 & $\begin{array}{l}\text { Science Direct, IEEE Xplore, Hindawi, and } \\
\text { Taylor \& Francis Online, SpringerLink, and } \\
\text { Google Scholar. }\end{array}$ & $\begin{array}{l}\text { Inderscience } \\
\text { Publishers }\end{array}$ \\
\hline
\end{tabular}

Table 2 details that literature reviews analyze 90 documents on average, and specifically, $43 \%$ of literature reviews analyze from 33 to 56 documents, $18 \%$ literature reviews study from 60 to 91 documents, and 25\% reviews of literature analyze more than 100 documents. Similarly, the period covered in literature reviews is 16 years on average and the most relevant publishers for literature reviews of supplier selection are Elsevier, Taylor \& Francis, Growing Science, and Inderscience. Table 2 also shows that $29 \%$ of the documents cover periods between 4 and 10 years, while $32 \%$ analyze a period between 11 and 15 years, 29\% of literature reviews study a time horizon between 16 and 50 years, and $10 \%$ of literature reviews do not mention the period (Abdolshah, 2013; Ghadimi and Heavey, 2015; Zhang et al., 2014).

Due to the increasing number of publications in recent years regarding supplier selection (Figure 1), future literature reviews should consider short time periods, between 3 and 5 years, allowing analyzing new advances in specific themes of supplier selection, complementing existing literature reviews and avoiding the replication of information published and analyzed by other authors.

\section{Conclusions}

In this article, 28 literature reviews of supplier selection between 2000 and 2018 were analyzed, identifying that supplier selection is a multidisciplinary process involving areas such as engineering, business, management and accounting, computer science, decision science, and mathematics. Likewise, it is suggested to conduct literature reviews addressing risk management for supplier selection. Literature reviews of statistical methods in supplier selection are also encouraged, including techniques such as factor analysis, data mining, analysis of variance, multiple regression, decision trees, discriminant analysis, multivariate analysis of variance, sensitivity analysis, among others. These methods have been mentioned only by Alkahtani \& Kaid (2018), but it is necessary to deepen in the utility and relevance of these methods for specific cases.

Another research opportunity is related to performing literature reviews focused on the application of supplier selection to real sectors, analyzing how methods and criteria are adjusted and selected according to the specific situation of each company. For example, future research could analyze which supplier selection models are used and how they differ from others for the Electric-Electronic sector, which represents the industry with the largest number of applications in the literature (Junior et al., 2013; Zimmer et al., 2016). Researchers interested in supplier selection are also encouraged to propose literature reviews of supplier selection methods and criteria for small and medium-sized companies, highlighting the differences with the approaches for large companies, and recommending computer environments to develop solution methods for companies with limited resources.

To the best of our knowledge, there are still no literature reviews of supplier selection allowing to compare the relevance and performance of supplier selection methods. This represents an opportunity to propose a guide to compare individual methods and hybrid methods, to the point of suggesting which combination of these methods are most effective under specific conditions of the supplier selection process. Additionally, it is recommended to review decisionmaking methods used in other areas of knowledge with similar conditions and objectives to those of the supplier selection, 
such as in international market selection (Baena, Cano, \& Campo, 2018; Cano, Baena, \& Campo, 2019; Cano, Campo, \& Baena, 2017; Cano, Campo, \& Gómez, 2017), and identify which methods have not been applied for supplier selection in order to appropriate the said methods and improve the efficiency of this supply chain process. Similarly, studies such as Cano \& Baena (2015a, 2015b) can be applied to review the information and communication technologies used to support the supplier selection process.

Likewise, it is suggested to continue presenting literature reviews of green and sustainable supplier selection, and also in topics related to uncertainty management, both through stochastic and fuzzy methods. Based on the growing trend of published documents, we recommend focusing future literature reviews in short time periods between 3 and 5 years, thus analyzing the contribution of new documents and avoiding the repetition of information provided by other authors.

Finally, future literature reviews could be sent for publication in journals such as Expert Systems With Applications, International Journal of Production Economics, International Journal of Advanced Manufacturing Technology, Computers And Industrial Engineering, Mathematical Problems In Engineering, International Journal of Logistics Systems And Management, International Journal of Services And Operations Management, being journals with a high number of publications and lacking in literature reviews on this topic. The relevance of these proposed journals will correspond to the specific topic addressed in the literature review of supplier selection.

\section{References}

1. Aamer, A. M., \& Sawhney, R. (2004) 'Review of suppliers selection from a production perspective,' IIE Annual Conference and Exhibition 2004, (January 2004), 2135-2140.

2. Abdolshah, M. (2013) 'A Review of Quality Criteria Supporting Supplier
Selection,' Journal of Quality and Reliability Engineering, 2013, 1-9.

3. Agarwal, P., Sahai, M., Mishra, V., Bag, M., \& Singh, V. (2011) 'A review of multicriteria decision making techniques for supplier evaluation and selection,' International Journal of Industrial Engineering Computations, 2(4), 801-810.

4. Aissaoui, N., Haouari, M., \& Hassini, E. (2007) 'Supplier selection and order lot sizing modeling: A review,' Computers and Operations Research, 34(12), 3516-3540.

5. Alkahtani, M., \& Kaid, H. (2018) 'Supplier selection in supply chain management: a review study,' International Journal of Business Performance and Supply Chain Modelling, 10(2), 107.

6. Amin-Tahmasbi, H., \& Alfi, S. (2018) 'A fuzzy multi-criteria decision model for integrated suppliers selection and optimal order allocation in the green supply chain,' Decision Science Letters, 7(1), 549-566.

7. Baena, J. J., Cano, J. A., \& Campo, E. A. (2018) 'Metodología para la Selección de Mercados Internacionales: Un Análisis de Caso para la Exportación de Bebidas Carbonatadas,' Dirección Y Organización, 66(1), 5-16.

8. Boran, F. E., Genç, S., Kurt, M., \& Akay, D. (2009) 'A multi-criteria intuitionistic fuzzy group decision making for supplier selection with TOPSIS method,' Expert Systems with Applications, 36(8), 1136311368.

9. Cano, J.A., \& Baena, J. J. (2015a) 'Impact of Information and Communication Technologies in International Negotiation Performance,' Review of Business Management, 17(54), 751-768.

10. Cano, J.A., \& Baena, J. J. (2015b) 'Tendencias en el uso de las tecnologías de información y comunicación para la negociación internacional,' Estudios Gerenciales, 31(136), 335-346.

11. Cano, J.A., Baena, J. J., \& Campo, E.A. (2019) 'International Market Selection Methodology for Exporting Cheese from Colombia,' Proceedings of the 32nd International Business Information Management Association Conference - Vision 2020: Sustainable Economic Development and Application of Innovation Management from Regional expansion to Global Growth (pp. 3763-3772). Seville, Spain: IBIMA.

12. Cano, J.A., Campo, E., \& Baena, J. (2017) 
'Application of DEA in international market selection for the export of goods,' DYNA (Colombia), 84(200), 376-382.

13. Cano, J.A., Campo, E., \& Gómez, R. (2017) 'International Market Selection Using Weighing and Monte Carlo Simulation,' Polish Journal of Management Studies, 16(2), 40-50.

14. Cano, J.A., Panizo, C. A., García, F. H., \& Rodríguez, J. E. (2015) 'Estrategias para el mejoramiento la cadena de suministro del carbón en Norte de Santander, Colombia. Boletín de Ciencias de La Tierra, 1(38), 6574.

15. Chai, J., Liu, J. N. K., \& Ngai, E. W. T. (2013) 'Application of decision-making techniques in supplier selection: A systematic review of literature,' Expert Systems with Applications, 40(10), 38723885.

16. Chakraborty, P. S. (2015) 'A review on supplier selection problem in regular area of application,' International Journal of Applied Engineering Research, 10(62), 128132.

17. Chen, Y. J. (2011) 'Structured methodology for supplier selection and evaluation in a supply chain,' Information Sciences, 181(9), 1651-1670.

18. De Boer, L., Labro, E., \& Morlacchi, P. (2001) 'A review of methods supporting supplier selection,' European Journal of Purchasing and Supply Management, 7(2), 75-89.

19. Deshmukh, A. J., \& Chaudhari, A. A. (2011), A review for supplier selection criteria and methods. In K. Shah, V. R. Lakshmi Gorty, \& A. Phirke (Eds.), Technology Systems and Management. Communications in Computer and Information Science (Vol. 145, pp. 283-291). Berlin, Heidelberg: Springer.

20. Drake, P. R., Myung Lee, D., \& Hussain, M. (2013) 'The lean and agile purchasing portfolio model,' Supply Chain Management: An International Journal, 18(1), 3-20.

21. Ghadimi, P., \& Heavey, C. (2015) 'A review of applications of agent-based modelling and simulation in supplier selection problem,' Proceedings - 8th EUROSIM Congress on Modelling and Simulation, EUROSIM 2013, 101-107.

22. Ghodsypour, S. H., \& O'Brien, C. (2001) 'The total cost of logistics in supplier selection, under conditions of multiple sourcing, multiple criteria and capacity constraint,' International Journal of Production Economics, 73(1), 15-27.

23. Ghorabaee, M. K., Amiri, M., Zavadskas, E. K., \& Antucheviciene, J. (2017) 'Supplier evaluation and selection in fuzzy environments: A review of MADM approaches,' Economic ResearchEkonomska Istrazivanja , 30(1), 1073-1118. 24. Gómez, R.A., Cano, J.A., \& Campo, E.A. (2015) 'Selección de proveedores en la minería de oro con lógica difusa,' Revista Venezolana de Gerencia (RVG), 21(75), 530548.

25. Govindan, K., Rajendran, S., Sarkis, J., \& Murugesan, P. (2015) 'Multi criteria decision making approaches for green supplier evaluation and selection: A literature review,' Journal of Cleaner Production, 98, 66-83.

26. Ho, W., Xu, X., \& Dey, P. K. (2010) 'Multicriteria decision making approaches for supplier evaluation and selection: A literature review,' European Journal of Operational Research, 202(1), 16-24.

27. Igarashi, M., De Boer, L., \& Fet, A. M. (2013) 'What is required for greener supplier selection? A literature review and conceptual model development,' Journal of Purchasing and Supply Management, 19(4), 247-263.

28. Junior, F. R. L., Osiro, L., \& Carpinetti, L. C. R. (2013) 'Multicriteria decision methods for supplier selection: A literature review on the state of the art,' Gestao E Producao, 20(4), 781-801.

29. Karsak, E. E., \& Dursun, M. (2016) 'Taxonomy and review of non-deterministic analytical methods for supplier selection,' International Journal of Computer Integrated Manufacturing, 29(3), 263-286.

30. Kellner, F., Lienland, B., \& Utz, S. (2018) 'An a posteriori decision support methodology for solving the multi-criteria supplier selection problem,' European Journal of Operational Research, 0, 1-18.

31. Khodadadzadeh, T., \& Sadjadi, S. J. (2013) 'A state-of-art review on supplier selection problem,' Decision Science Letters, 2(2), 59-70.

32. Murray, J. G. (2009) 'Towards a common understanding of the differences between purchasing, procurement and commissioning in the UK public sector,' Journal of Purchasing and Supply 
Management, 15(3), 198-202.

33. My Dung, T. T., Luan, N. M., \& Quoc, L. H. (201) 'The analytic approach applications in green supplier selection: A literature review,' ARPN Journal of Engineering and Applied Sciences, 11(11), 6754-6762.

34. Ocampo, L. A., Abad, G. K. M., Cabusas, K. G. L., Padon, M. L. A., \& Sevilla, N. C. (2018) 'Recent approaches to supplier selection: A review of literature within 2006-2016,' International Journal of Integrated Supply Management, 12(1/2), 22.

35. Renganath, K. (2017) 'Supplier Selection Using Fuzzy MCDM Techniques: A Literature Review,' 2016 IEEE International Conference on Computational Intelligence and Computing Research (pp. 1-6). Tamil Nadu, India: IEEE.

36. Ristono, A., Pratikto, P., Santoso, P. B., \& Tama, I. P. (2018) 'A literature review of criteria selection in supplier,' Journal of Industrial Engineering and Management, 11(4), 680.

37. Setak, M., Sharifi, S., \& Alimohammadian, A. (2012) 'Supplier selection and order allocation models in supply chain management: A review,' World Applied Sciences Journal, 18(1), 55-72.

38. Simić, D., Kovačević, I., Svirčević, V., \& Simić, S. (2017) ‘50 years of fuzzy set theory and models for supplier assessment and selection: A literature review,' Journal of Applied Logic, 24, 85-96.

39. Viana, J. C., \& Alencar, L. H. (2012) 'Metodologias para seleção de fornecedores: uma revisão da literatura,' Producao, 22(4), 625-636.

40. Villanueva-Ponce, R., Avelar-Sosa, L., Alvarado-Iniesta, A., \& Cruz-Sánchez, V. G. (2015) 'The green supplier selection as a key element in a supply chain: A review of cases studies,' Dyna, 82(194), 36-45.

41. Yildiz, A., \& Yayla, A. Y. (2015) 'MultiCriteria Decision-Making Methods for Supplier Selection: a Literature Review,' South African Journal of Industrial Engineering, 26(2), 158-177.

42. Zhang, D. W., Abdul Hamid, A. B., \& Thoo, A. C. (2014) 'Sustainable Supplier Selection: An International Comparative Literature Review for Future Investigation,' Applied Mechanics and Materials, 525, 787790.

43. Zimmer, K., Fröhling, M., \& Schultmann, F. (2016) 'Sustainable supplier management - A review of models supporting sustainable supplier selection, monitoring and development,' International Journal of Production Research, 54(5), 14121442. 